\title{
Development of Mobile Learning Media on Newton's Laws Using the Appy Pie Application
}

\author{
Renny Firdawati ${ }^{1}$, Maison $^{1 *}$ Nazarudin $^{1}$ \\ ${ }^{1}$ Master of Science Education Program, Universitas Jambi, Jambi, Indonesia.
}

DOI: $\underline{10.29303 / j p p i p a . v 7 i 2.599}$

\section{Article Info}

Received : January $22^{\text {th }}, 2021$

Revised : April 8th, 2021

Accepted: April 10th, 2021

\begin{abstract}
This research and development aim to develop mobile learning media using the Appy Pie application for high school students. The research and development stages are carried out using the ADDIE model. The instruments used for validation in this development research are (1) a validation questionnaire filled in by the validator to determine the media's feasibility, (2) a teacher and student response questionnaire to assess user perceptions of the media used. There are two kinds of data collecting and analysis methods: qualitative methods to collect data and describe comments and suggestions for improvement from the validators and quantitative methods to collect and analyze responses from teachers and students. Based on the validation results of media development carried out by design, material, and media experts, it is stated that the media is valid and can be tested. The results of the teacher's response obtained a percentage of $90 \%$ in the very good category, the results of student responses in the one-on-one trial obtained a rate of $91.56 \%$ in the very good category, the results of student responses in small group trials received a percentage of $90.27 \%$ in the very good category.
\end{abstract}

Keywords: Mobile learning media; Appy Pie application; Newton's Laws

Citation: $\quad$ Firdawati, R., Maison, M., \& Nazarudin, N. (2021). Development of Mobile Learning Media on Newton's Laws Using the Appy Pie Application. Jurnal Penelitian Pendidikan IPA, 7(2), 202-206. doi:https://doi.org/10.29303/ippipa.v7i2.599

\section{Introduction}

Science and technology are developing rapidly in education from various strategies and patterns (Rahmat, 2019). The use of technology in the teaching and learning process as an interactive medium can increase student motivation. Motivation to learn is an encouragement to carry out the learning process. Students who have high motivation will have the enthusiasm and energy to carry out their daily learning activities. Therefore learning motivation is related to student learning outcomes at school (Ramdani et al., 2019)

According to Asyhar (2012), the media has a vital role: a means or device that functions as an intermediary or channel in a communication process between communicators and communicants.
Availability of media is very important to stimulate student learning activities (Ahmad, 2019). Various forms and types of learning media can be sources of knowledge for students (Amirullah et al., 2017). Messages still in the speaker's mind will not reach the recipient of the message if a medium does not assist them as an intermediary. Likewise, according to Rusli et al. (2017), learning media is part of the delivery strategy.

The use of instructional media in the teaching and learning process can generate new desires and interests, motivation, stimulation of learning activities, and even psychological influences. To support the achievement of varied media learning objectives, it is very necessary (Qosyim et al., 2017). The function of learning media is a demonstration for teachers, carriers of information, or teaching messages needed by 
students (Jamuri, 2015). The use of instructional media at the learning orientation stage will significantly assist the learning process's effectiveness and the delivery of messages and lesson content. In addition to arousing student motivation and interest, learning media can also improve understanding, present data attractively and reliably, facilitate data interpretation, and condense information (Arsyad, 2011).

Learning media can be developed by utilizing android or smartphone-based media technology (Kuswanto \& Radiansah, 2018) or better known as mobile learning. According to Darmawan (2016), Mobile learning is a transition from subordinate electronic learning methods to independent learning, allows materials to be designed with attractive visuals and accessed from outside the school. Mobile learning can improve the quality of learning effectively and efficiently (Sulisworo \& Toifur, 2016) and assist students in the learning process (Ratnasari et al., 2020).

The Android operating system, which has the advantage of being software that uses a computer code base that can be distributed openly (open source), allows users to create new applications. As in the Appy Pie application, users create and monetize various kinds of mobile applications, take advantage of mobile learning media, and be developed as a medium for teaching materials. The Appy Pie application is one of the online builders available on the internet. Appy Pie can support the process of creating applications based on Android, Mac OS, Windows Phone, Blackberry, and HTML 5 (Astuti et al., 2017). An online app builder is a website that can be used to process application development.

By using an online builder, the application development process will become easier. Most of the application development through the online app builder is through a drag and drop process. Features such as layouts, icons, and buttons are available in the builder with many options. The coding process is not required. Appy Pie is a website that provides a template for making android applications. In making media with Appy Pie, users must be connected directly to the internet. Learning materials can contain text, images, videos, links, and interactive quizzes (Hapidz et al., 2019). One of the advantages of Appy pie is that it makes it easier for students to learn because it can be taken anywhere and is familiar and close to students so that students are more interested in its use (Suparyati, 2018).

According to Mulhall \& Gunstone (2012), students' dependence on physics teachers is still very high because students think learning physics is difficult. One-way transfer of knowledge, causing boredom and difficulty understanding physics lessons (Doyan, A. et al., 2018). The learning process with many formulas and concepts makes students confused in learning (Nurmayani et al., 2018). Some physics materials, such as Newton's Law, are still relatively difficult for students to understand even though the phenomenon is often encountered in everyday life. Students have not been able to take advantage of this phenomenon to learn Newton's Laws independently. Some obstacles such as utilizing existing facilities, information in schools that do not support ideal physics learning, mismatching face-to-face time with the amount of material that must be studied are difficult factors for teachers in innovating to develop learning media (Anggraeni et al., 2015). Therefore, it is necessary to develop a mobile learning media that can bridge the phenomenon of motion experienced or observed by students into knowledge.

Several previous studies have shown that Android-based mobile learning media can help students learn because they are practical and flexible (Astuti et al., 2017) and can be used for individual learning (Purnama et al., 2017) and affect student awareness in learning (Maison et al., 2020). The obstacles that arise also come from integrating the concept appropriately and efficiently because students have knowledge and experience related to physical phenomena directly in everyday life (Shilla et al., 2017). Therefore, this research aims to develop mobile learning media for Newton's Law using the Appy Pie application to be easier to understand and more flexible for students to use.

\section{Method}

This type of research is development research using the ADDIE model, a systematic learning model design and consists of five stages: analysis, design, development, implementation, and evaluation. According to Rusdi (2018), the ADDIE framework is a major stage, while to design the steps that are carried out in these stages, researchers can be creative in their design and development.

In the development process, three experts and two practitioners (physics teacher) conducted product validation. Research respondents were teachers and students of class X SMA N 3 Muaro Jambi. Individual trials (one on one) were performed on three students, and small group trials were carried out on ten students.

Data collection was carried out through observation, interviews, documentation, and questionnaires. The instruments used in the study were a questionnaire for teacher assessment, one-on-one trials, and small groups. Following the type of data, the data analysis techniques used are qualitative and quantitative data analysis techniques. Qualitative data analysis was carried out on observation data, 
interviews, and data from open questionnaires. Meanwhile, quantitative data analysis was carried out on data from closed questionnaires, namely student response questionnaires using the Likert scale. Then to calculate the percentage of eligibility using the formula (1):

Media eligibility $=\frac{\sum \text { total score }}{\text { expected score }} \times 100 \%$

The distribution of the range of eligibility categories can be seen in Table 1.

Table 1: Eligibility percentage criteria

\begin{tabular}{lll}
\hline Scale & Value scale & Validation level \\
\hline 5 & $81 \%-100 \%$ & Very eligible \\
4 & $61 \%-80 \%$ & Eligible \\
3 & $41 \%-60 \%$ & Fairly eligible \\
2 & $21 \%-40 \%$ & Not eligible \\
1 & $<21 \%$ & Very not eligible \\
\hline
\end{tabular}

\section{Result and Discussion}

The results of the development of this research are (1) a mobile learning media using the Appy Pie application on Newton's Law material, (2) validation of design, media, and learning materials in the development process carried out by design experts, media experts and material experts, and (3) assessment or response by all respondents consisting of one-on-one trials and small group trials as well as teacher responses to mobile learning media that have been developed using the Appy Pie application.

The teacher's needs, student characteristics, learning materials, and learning environment are obtained in the analysis stage. Based on the needs analysis, a design was carried out that resulted in a mobile learning media design using the Appy Pie application, an example of which is shown in Figure 1.

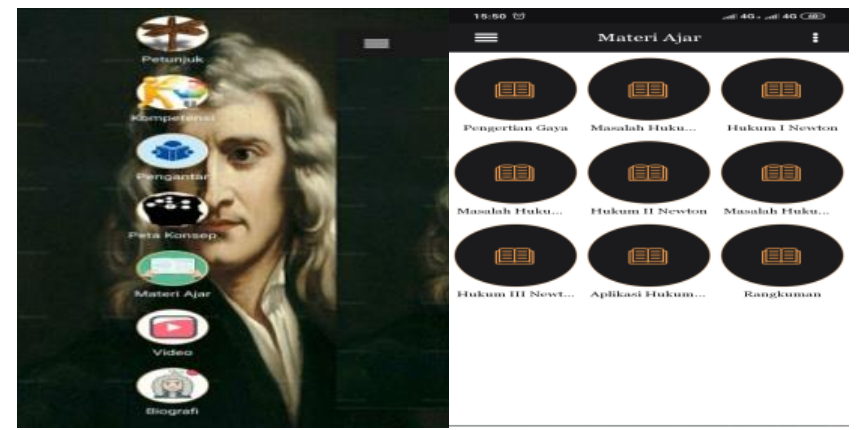

Figure 1. Some examples of display media

This product can combine text, video/animation, and images in one learning medium, displays real pictures in everyday life to make it easier for students to understand, and provide interactive practice questions.

After going through several formative revisions in the development stage, this product has been declared valid by a validator of material, media, and design experts. Furthermore, based on two physics teachers' trials using a teacher response questionnaire consisting of 14 questions using a Likert scale where the scoring is as follows: very good $=5$, good $=4$, enough $=3$, bad $=2$, very bad $=1$ show that the media is said to be attractive and can be used as supporting teaching material in the learning process, and is feasible to be tested on students; This can be seen from the percentage of teacher response trials as in Figure 2:

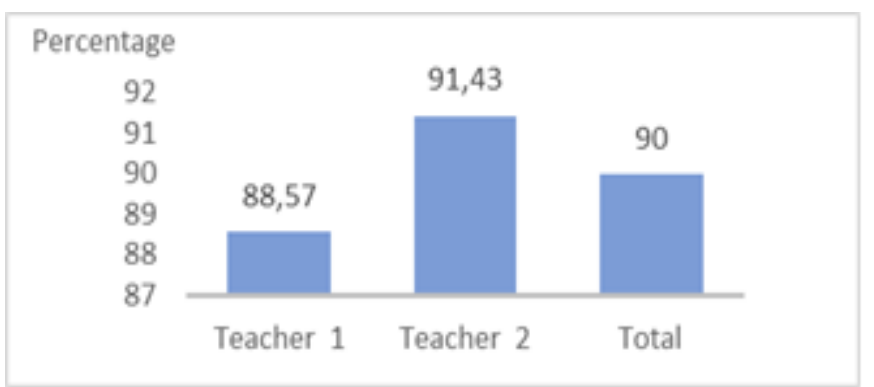

Figure 2. Teacher response diagram

The percentage of teacher 1 responses (Figure 2) was $88.57 \%$, and teacher 2 was $91.43 \%$. After totaling, the average percentage of the two teachers' responses was $90 \%$ in the very good category.

The results of one-on-one trials were carried out on three students as respondents; from the assessments given and then analyzed, data was obtained as in Figure 3.

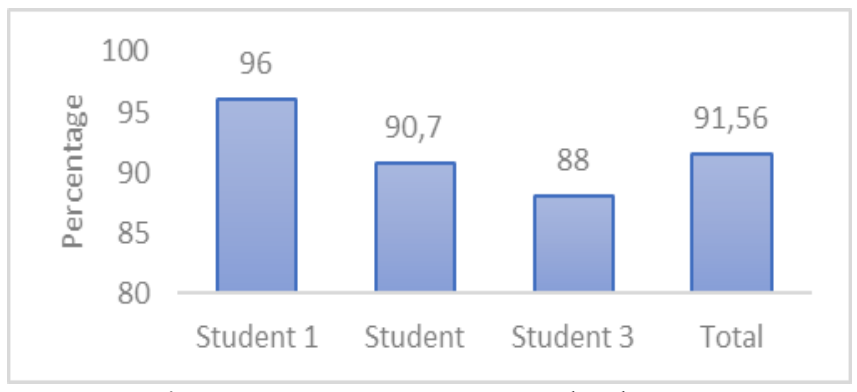

Figure 3. One-on-one test results diagram

The average percentage of one-on-one trials (Figure 3) is $91.56 \%$, which is very feasible or very good. There is an agreement on the three respondents' perception that the media developed is very good and suitable for use.

Small group trials were carried out on ten students as respondents; from the assessments given and then analyzed, data was obtained as in Figure 4. 


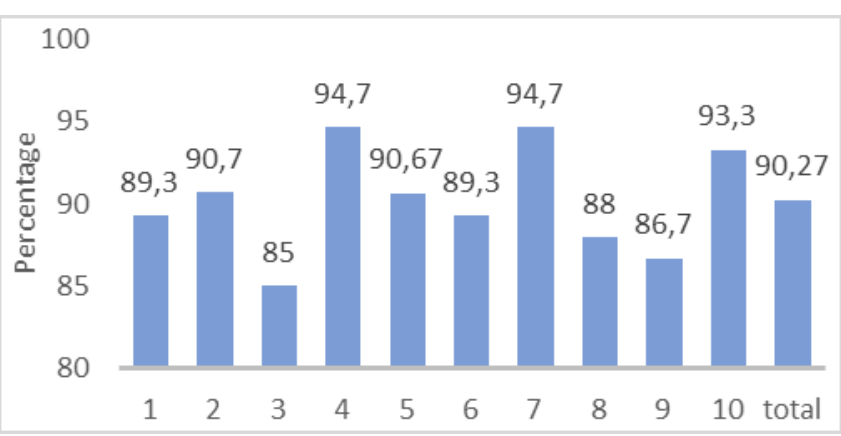

Figure 4. Small group trial results diagram

The average percentage of small group trial responses (Figure 4) was $90.27 \%$, which was very good. Even though there is a difference in the percentage value, there is an agreement among respondents that the media they use is in the very good category.

Based on the validation results of all experts (material, media, and design validators), teacher responses, one-on-one trials, and small group trials, it appears that Newton's Laws media is feasible to use, makes it easy, and attracts students' interest to learn.

\section{Conclusion}

This development research concludes that the mobile learning media of Newton's law developed using the Appy Pie application are categorized as valid according to the validators and get a very good response from teachers and students who use them.

\section{Acknowledgments}

The authors would like to thank the Directorate General of Higher Education for financial support.

\section{References}

Amirullah, G., \& Hardinata, R., (2017). Pengembangan mobile learning bagi pembelajaran. JKKP: Jurnal Kesejahteraan Keluarga dan Pendidikan, 4(2). doi: https://doi.org/10.21009/JKKP.042.07 [Indonesian]

Anggraeni, D. M., Susilawati, Gunawan. (2015). Pengaruh media pembelajaran berbasis moodle terhadap peningkatan kemampuan generic sains siswa SMK. Jurnal Penelitian Pendidikan IPA, 1(1). doi:https://doi.org/10.29303/ippipa.v1i1.256 [Indonesian]

Arsyad, A. (2011). Media pembelajaran. Jakarta: PT. RajaGrafindo Persada. [Indonesian]

Astuti, I. A. D., Sumarni, R. A., \& Saraswati, D. L. (2017). Pengembangan media pembelajaran mobile learning berbasis android pada materi sifat koligatif larutan. JRPK: Jurnal Riset Pendidikan
Kimia, 3(1), 57-62. doi: https://doi.org/10.21009/jrpk.072.10

[Indonesian]

Asyhar, R. (2012). Kreatif mengembangkan media pembelajaran. Jakarta: Referensi. [Indonesian]

Darmawan, D. (2016). Mobile learning sebuah aplikasi teknologi pembelajaran. Jakarta: PT. RajaGrafindo Persada. [Indonesian]

Doyan, A., Taufik, M., \& Anjani, R. (2018). Pengaruh pendekatan multi respresentasi terhadap hasil belajar fisika ditinjau dari motivasi belajar peserta didik. Jurnal Penelitian Pendidikan IPA, 4(1). doi:https://doi.org/10.29303/ippipa.v4i1.99 [Indonesian]

Jamuri, Kosim, \& Doyan, A. (2015). Pengaruh model pembelajaran kooperatif STAD berbasis multimedia interaktif terhadap penugasan konsep siswa pada materi termodinamika. Jurnal Penelitian Pendidikan IPA, 1(1). doi:https://doi.org/10.29303/ippipa.v1i1.11 [Indonesian]

Hapidz, R. A., Sumardi, K., \& Komaro, M. (2019). Desain dan pembuatan media pembelajaran mobile learning pada mata pelajaran sistem dan instalasi tata udara. Journal of Mechanical Engineering Education, 6(1), 71-79. doi: https://doi.org/10.17509/jmee.v6i1.18245 [Indonesian]

Kuswanto, J., \& Radiansah, F. (2018). Media Pembelajaran Berbasis Android Pada Mata Pelajaran Sistem Operasi Jaringan Kelas XI. JURNAL MEDIA INFOTAMA, 14(1). doi: https://doi.org/10.37676/jmi.v14i1.467 [Indonesian]

Maison, Kurniawan, D. A., \& Anggraini, L. (2020). The influence of online learning on students' awareness in doing assignments during Covid-19 pandemic. Ta'dib, 23(2), 171-178. doi: http://dx.doi.org/10.31958/jt.v23i2.2416

Mulhall, P., \& Gunstone, R. (2012). Views about learning physics held by physics teachers with differing approaches to teaching physics. Journal of Science Teacher Education, 23(5), 429-449. doi: https://doi.org/10.1007/s10972-012-9291-2

Nurmayani, L., Doyan, A., \& Verawati, N. S. P., (2018). Pengaruh model pembelajaran inkuiri terbimbingterhadap hasil belajar fisika. Jurnal Penelitian Pendidikan IPA, 4(2). doi:https://doi.org/10.29303/ippipa.v4i2.113 [Indonesian]

Purnama, R., Sesunan, F., \& Ertikanto, C. (2017). Pengembangan media pembelajaran mobile learning berbasis android sebagai suplemen pembelajaran fisika SMA pada materi usaha dan energi. Jurnal Pembelajaran Fisika Universitas 
Lampung, 5(4). [Indonesian]

Qosyim, A., \& Priyonggo , F. V., (2017). Penerapan media pembelajaran interaktif menggunakan flash untuk materisistem gerak pada manusia. JPPIPA: Jurnal Penelitian Pendidikan IPA, 2(2). doi:http://dx.doi.org/10.26740/jppipa.v2n2.p38$\underline{44}$ [Indonesian]

Rahmat, H. K., (2019). Mobile learning berbasis appypie sebagai inovasi media pendidikan untuk digital natives dalam perspektif islam. Jurnal Tarbawi, 16(1). doi: https://doi.org/10.34001/tarbawi.v16i1.999

Ramdani, A., Jufri A. W., Gunawan, Saputra H. S., \& Zulkifli, L., (2019). Pengembangan alat evaluasi pembelajaran IPA yang mendukung keterampilan Abad 21. Jurnal Penelitian Pendidikan IPA, 5(1). doi:https://doi.org/10.29303/jppipa.v5i1.221 [Indonesian]

Ratnasari, D., Oktaviyanti, D., Sukmawati, S. S., \& Setiyawati, E. (2020). Pengembangan mobile 6learning berbasis program APPYPIE untuk pembelajaran fisika. Jurnal Penelitian Pendidikan Fisika, 5(2), 158-163. doi: http://dx.doi.org/10.36709/jipfi.v5i2.13149 [Indonesian]

Rusli, M., Hermawan, D., \& Supuwiningsih, N. N. (2017). Multimedia pembelajaran yang inovatif: Prinsip dasar dan model pengembangan. Yogyakarta: Penerbit ANDI. [Indonesian]

Shilla, R. A., Kusairi, S., \& Hidayat, A. (2017). Penguasaan konsep siswa pada materi Hukum Newton tentang gerak. Seminar Pendidikan IPA Pascasarjana UM, 257-263. [Indonesian]

Sulisworo, D., \& Toifur, M. (2016). The role of mobile learning on the learning environment shifting at high school in Indonesia. Int. J. Mobile Learning and Organisation, 10(3).

Suparyati, A. (2018). Peningkatan minat belajar siswa terhadap pembelajaran animasi 2D melalui media berbasis android Appy Pie di sekolah menengah kejuruan. Edudikara: Jurnal Pendidikan Dan Pembelajaran, 3(2), 180-189. doi: https://doi.org/10.32585/edudikara.v3i2.98 [Indonesian]

Syawaludin, A., Makkasau, A., \& Jamal, F. I. (2019) Pengembangan media pembelajaran berbasis aplikasi Lectora inspire pada mata pelajaran IPS kelas V. JIKAP PGSD: Jurnal ilmiah ilmu kependidikan, 3(3). [Indonesian] 